\title{
Floc compaction during ballasted aggregation
}

\author{
J. SIELIECHI ${ }^{1 *}$, B. LARTIGES ${ }^{2 *}$, S. SKALI-LAMI ${ }^{3}$, J. KAYEM ${ }^{1}$, R. KAMGA ${ }^{1}$ \\ ${ }^{1}$ ENSAIT-IUT - University of Ngaoudere - P.O. Box 455 - Cameroon. \\ ${ }^{2}$ University of Toulouse (Paul Sabatier) - Geosciences Environment Toulouse UMR CNRS- \\ UPS 5563 - 14 Av. Edouard Belin - 31400 Toulouse, France. \\ ${ }^{3}$ University of Lorraine - LEMTA-ENSEM/INPL-CNRS, 2 Avenue de la Forêt de Haye - BP \\ 160 - 54504 Vandoeuvre Cedex, France.
}

(*) To whom correspondence should be addressed

E-mail: bruno.lartiges@get.omp.eu

joseph.sieliechi@yahoo.fr

\begin{abstract}
Ballasted aggregation, a process using the addition of a ballasting agent to improve the settling performance of flocs, appears particularly appropriate for the treatment of humic rich waters that leads to low-density aggregates. In that context, using an aquagenic humic acid coagulated by ferric chloride in the presence of pozzolana particles as ballasting agent, we show that the origin of improved floc settling in ballasted aggregation is not simply related to an increased specific weight of flocs, but also to a significant restructuring of flocs to a more compact structure induced by the added particles. The floc restructuring is evidenced from the increased lag time before measurable floc growth in the presence of the ballasting agent, the higher fractal dimension of flocs above the micron scale range after incorporation of the particles into the aggregates, and a much smaller sediment volume after settling. A simple model of floc compaction based on the turbulent viscous effects that act on an elastic floc, is described.
\end{abstract}

Key words: ballasted aggregation, humic acid, floc compaction, floc restructuring, fractal dimension, ballasting agent 


\section{INTRODUCTION}

In water treatment, the primary objective of coagulation-flocculation process is to gather the finely divided matter suspended in the raw water within large flocs that can settle rapidly. However, because of the fractal organization of flocs, the aggregate growth is necessarily accompanied by a decrease in floc density which impairs the performance of floc settling (Bache and Gregory, 2007; Tambo and Watanabe, 1979). Such effect becomes particularly challenging for coloured raw waters rich in humic substances, that lead to light and fragile structures with poor settling characteristics (Eikebrokk, 1999; Jarvis et al., 2005; Sieliechi et al., 2008).

To improve the removal efficiency of fractal flocs, two main approaches have been considered: (i) the aggregate can be compacted upon exposure to increased shear, (ii) a highdensity particle - the ballasting agent - is attached to the aggregate, thus directly increasing its specific weight. While the former has been adressed in numerous simulation and experimental studies (Becker et al., 2009; Clark and Flora, 1991; Oles 1992; Selomulya et al., 2001; Seto et al., 2012; Spicer et al., 1998, Thill et al., 2001), the approach has received little attention in industrial practice. Indeed, if coagulated latex flocs submitted either to growth/breakage/regrowth cycles or prolonged shearing show an increased compaction of aggregates (Jarvis et al., 2005; Oles 1992; Selomulya et al., 2001; Selomulya et al., 2003; Serra and Casamitjana, 1998; Spicer et al., 1998), these results do not systematically apply to aggregates formed using hydrolyzing metal coagulants (Clark and Flora 1991; Jarvis et al., 2005; Yukselen and Gregory, 2004). In some cases, a reduced fractal dimension is even observed during floc re-growth after the breakup stage (Jarvis et al., 2005; Spicer et al., 1998).

In contrast, ballasted-aggregation is now widely used for the treatment of surface waters, wastewaters, and combined sewer overflows, most often under the trade name 
ACTIFLO $^{\circledR}$ (Gasperi et al., 2012; Plum et al., 1998). However, if the most pertinent process parameters - concentration and size distribution of ballasting agent, velocity gradient and stirring time, polymer dosage - can be optimized according to the type of water to be treated (Cailleaux et al., 1992; de Dianous and Dernaucourt, 1991), the scientific literature investigating the detailed mechanims of ballasted floc formation remains scarce (Desjardins et al., 2002; Ghanem et al., 2007; Lapointe and Barbeau, 2016; Young and Edwards, 2003). Thus, whether the ballasting agent may act as a nucleus during floc growth (Cailleaux et al., 1992; Chaignon et al., 2002; Ghanem et al. 2007), the origin of enhanced binding strength of ballasted flocs (Young and Edwards, 2003), or the role of surface hydrophobicity on the attachment of ballasting agent to the forming aggregate (Defontaine et al., 2005; Piirtola et al., 1999), remain matters of debate.

In order to reach a better understanding of the mechanisms underlying ballasted aggregation in the case of strongly coloured waters, we investigate in this paper the coagulation of humic acid with ferric chloride in the presence of pozzolana particles as a ballasting agent. The removal of humic acid was evaluated by jar-testing, the kinetics of floc growth and the structural characteristics of ballasted aggregates were monitored with a laser sizer, and the nature of association reached between pozzolana and humic floc was examined using Transmission Electron Microscopy on resin-embedded samples. We show that the addition of a ballasting agent induces a significant compaction of flocs that can be modelled by considering the turbulent viscous effects that act on an elastic floc.

\section{EXPERIMENTAL SECTION}

2.1 Materials. The humic acid used in this study, referred to as NHA hereafter, was extracted from Nyong river sediment (Cameroon) following the procedure described in Thurman and 
Malcom (1981), which was adapted to yield the natural extract in a sodium form (Jung et al., 2005). The main characteristics of NHA (chemical composition, FTIR and CP/MAS spectra) have been detailed in a previous paper (Sieliechi et al., 2008). The potentiometric titration yielded a total titratable charge of $2.97 \mathrm{meq} / \mathrm{g}$.

The pozzolana used as a ballasting agent comes from Djoungo quarry $\left(4.35^{\circ} \mathrm{N}\right.$, $9.37^{\circ} \mathrm{E}$ ) in southwestern Cameroon. If microsand is the usual particle in ballasted aggregation (Ghanem et al., 2007), pozzolana, commonly used in water treatment as a filter material, represents a potential alternative to microsand. The pozzolana was first crushed with a hammer-crusher (Retsch, Germany) to obtain particles of size lower than $600 \mu \mathrm{m}$, and after quartering, further ground with a vibratory disk mill (Retsch, Germany). The resulting powder was then screened through a $38 \mu \mathrm{m}$ sieve, the passing fraction being collected for the ballasted aggregation experiments. The median particle size of pozzolona ballast is $10.4 \mu \mathrm{m}$ (Mastersizer, Malvern Instruments), and the BET specific surface area measured by nitrogen adsorption at $77 \mathrm{~K}$ using a lab-made instrument is $2.6 \mathrm{~m}^{2} / \mathrm{g}$. The major element contents (ICPAES - Jobin Yvon 70), expressed as weight percent of oxides in Table S1 (See supporting information), falls within the range of typical pozzolana compositions (Cetin and Mehta, 1999; Sersale, 1980). X-ray diffraction analysis (Bruker D8) revealed that plagioclases $\left((\mathrm{Na}, \mathrm{Ca})(\mathrm{Al}, \mathrm{Si})_{4} \mathrm{O}_{8}\right)$ and augite $\left((\mathrm{Ca}, \mathrm{Na})(\mathrm{Fe}, \mathrm{Mg})(\mathrm{Si}, \mathrm{Al})_{2} \mathrm{O}_{6}\right)$ are the dominant crystalline minerals with a lesser amount of hematite $\left(\mathrm{Fe}_{2} \mathrm{O}_{3}\right)$.

2.2 Preparation of synthetic waters and aggregation procedure. The humic acid suspensions were obtained by dissolving NHA (25 mg/L i.e. a $10 \mathrm{mg} \mathrm{C} / \mathrm{L}$ dissolved organic carbon concentration) and $\mathrm{NaHCO}_{3}\left(410^{-3} \mathrm{~mol} / \mathrm{L}\right)$ in deionised water (Millipore - MilliQ). Sodium hydrogenocarbonate was added to provide a carbonate alcalinity similar to that of natural river waters. Prior to coagulant injection, the $\mathrm{pH}$ of synthetic waters was adjusted to $\mathrm{pH} 6$ or 8 
with dropwise addition of $0.1 \mathrm{M} \mathrm{HCl}$. The coagulant, a commercial ferric chloride kindly supplied by Groupe Arkema (France), is a $38 \% \mathrm{wt} \mathrm{FeCl}_{3}$ unhydrolyzed solution.

The aggregation experiments were conducted in $1 \mathrm{~L}$ reactors $(90 \mathrm{~mm}$ diameter, 150 mm high) fitted with 4 plexiglas baffles $(12 \times 150 \mathrm{~mm})$. Stirring was carried out with a rectangular paddle $(15 \times 55 \mathrm{~mm})$ located at one-third of the reactor height from the bottom. The mixing procedure started with a rapid mix period for 3 min at $250 \mathrm{rpm}$ (mean velocity gradient $\bar{\gamma}=452 \mathrm{~s}^{-1}$ ), followed by slow stirring at $60 \mathrm{rpm} \bar{\gamma}=84 \mathrm{~s}^{-1}$ ) for $30 \mathrm{~min}$. The coagulant was added under agitation as pure solution using a micro-pipette (Eppendorf). In the presence of pozzolana, a given amount of particles was first added to the NHA suspension for $5 \mathrm{~min}$ at $250 \mathrm{rpm}$, before the usual mixing procedure was triggered. At the end of mixing, the coagulated suspension was allowed to settle in graduated Imhoff cones. After $30 \mathrm{~min}$ and $24 \mathrm{~h}$ settling, $50 \mathrm{~mL}$ of supernatant were withdrawn with a syringe from about $25 \mathrm{~mm}$ below the free surface, for the monitoring of residual turbidity (Ratio XR Turbidimeter Hach), $\mathrm{pH}$ (Meter Lab PHM 210 Tacussel), and conductivity (CD 810 Tacussel). The sediment volume was also measured at both sampling times.

2.3 Aggregate size measurements and floc structure. After coagulant addition, the aggregation dynamics of NHA in the presence or in the absence of pozzolana particles was studied by following the temporal evolution of floc size distribution using a laser sizer (Malvern Instruments) in the 1.2-600 $\mu \mathrm{m}$ range. The suspension, agitated in the baffled reactor, was passed through the analyzer beam with a peristaltic pump located downstream of the measurement cell, and then recycled to the reactor. A pumping flow rate of $44 \mathrm{~mL} / \mathrm{min}$ and a tubing (Masterflex) of $4.6 \mathrm{~mm}$ in internal diameter, were selected for the experiments. Under these operating conditions, the floc size distribution is not significantly affected by the shear in the tubing, and the relative variations in aggregate size observed in the measurement 
cell can be related to the stirring speed in the reactor (Chaignon et al., 2002). Nevertheless, in the presence of ballasting agent, some settling of large pozzolana particles was found to occur in the tubing, which then limited the duration of valid measurements to about 3 minutes. Size measurements were averaged over $1 \mathrm{~s}$ and taken every $2 \mathrm{~s}$ to allow for a complete renewal of aggregates in the measurement cell.

In addition to the floc size distribution, the particle sizer provides an estimate of the apparent volume fraction $\phi$ of aggregates contained in the measurement cell. In the Fraunhofer approximation, the particles are viewed as opaque discs and $\phi$ can be determined from the obscuration of the laser beam using a Beer-Lambert law (Weiner, 1984). The fractal structure of aggregates is then characterized by the equation $\phi \sim \mathrm{d}_{50}{ }^{(3-\mathrm{Df})}$, where $\mathrm{d}_{50}$ is the median floc diameter and $\mathrm{D}_{\mathrm{f}}$ is the mass fractal dimension of aggregates (Oles, 1992).

2.4 Imaging of coagulated sediment. Transmission Electron Microscopy (TEM) observations of coagulated sediment were performed with a Phillips CM20 microscope on ultrathin slices cut from resin-embeded samples. Resin-embedding was carried out following a classical procedure (Sieliechi et al., 2008): in brief, coagulated samples were first chemically fixed with $2 \%$ osmium tetroxide for $1 \mathrm{~h}$, excess fixative being removed by washing with centrifuged treated water. Stepwise acetone dehydration (5 min at 10\%, 20\%, 40\%, and 60\%, $15 \mathrm{~min}$ at $80 \%, 2 \times 15 \mathrm{~min}$ at $95 \%$, and $3 \times 20 \mathrm{~min}$ at $100 \%$ acetone) was then conducted. Finally, acetone was exchanged with a graded series of epoxy resin monomers (Kit Embed 812, Euromedex), and the resin-impregnated samples were polymerized in molds at $60^{\circ} \mathrm{C}$ for $12 \mathrm{~h}$. The ultrathin sections $(\sim 1000 \AA)$ were cut using an ultramicrotome and a diamond knife (Reichert OM U2), and were placed on carbon-coated copper grids (Mesh 200, Euromedex). 
2.5 Electrophoretic measurements. The electrophoretic mobilities of pozzolana particles and aggregates of NHA/hydrolyzed coagulant, were measured with a Zetaphoremeter III (Sephy, France) equipped with a CCD camera. About $50 \mathrm{ml}$ of supernatant were pumped into the electrophoretic cell. The velocity of particles located at the stationary layer was then computed from frames taken at fixed time intervals under an $80 \mathrm{mV}$ voltage.

2.6 Adsorption isotherms. Batch adsorption tests were conducted at $\mathrm{pH} 6$ and 8 to assess the amount of NHA fixed on pozzolana particles. $250 \mathrm{mg}$ (i.e. $0.65 \mathrm{~m}^{2}$ ) of pozzolana were introduced into $50 \mathrm{~mL}$ polycarbonate centrifuge tubes containing $40 \mathrm{~mL}$ of synthetic suspension at the investigated $\mathrm{pH}$ and at a given NHA concentration. The suspensions were then agitated with an orbital shaker at room temperature for $5 \min$ and $24 \mathrm{~h}$. After centrifugation at $5000 \mathrm{rpm}$ (Ependorf Centrifuge) for 2 minutes, the supernatants were analyzed for dissolved organic carbon (Dohrmann DC-190 analyser). Blank tests were also run to estimate the amount of NHA adsorbed on walls of centrifuge tubes. The adsorbed NHA amount was then calculated from the difference between the total added NHA concentration and the supernatant concentration.

\section{RESULTS}

3.1 Interaction of $\mathrm{NHA}$ with pozzolana particles. The electrophoretic measurements revealed that the Djoungo pozzolana particles possess a negative surface charge from $\mathrm{pH} \geq 3$ (figure 1 ). The shape of the electrophoretic mobility curves - slight initial decrease at low $\mathrm{pH}$ followed by a steeper decrease around $\mathrm{pH} 7$ that stabilizes at higher $\mathrm{pHs}$ - implies the presence of at least two kinds of ionizable surface groups on the surface of pozzolana particles. 
Nyong humic acid is also negatively charged at $\mathrm{pH} 6$ and 8 due to the deprotonation of carboxylic and phenolic groups (Sieliechi et al., 2008). Nevertheless, as illustrated in figure 2, a small amount of NHA $\left(\sim 0.2 \mathrm{mg} \mathrm{C} / \mathrm{m}^{2}\right.$ at the plateau $)$ is adsorbed on Djoungo pozzolana at both pHs 6 and 8 for only a 5 minute conditioning time. Langmuir-type isotherms are obtained in all cases, and although the assumption of an energetically homogeneous surface is certainly not valid for pozzolana particles, a Langmuir analysis was performed (Table 1). After $24 \mathrm{~h}$, the adsorbed amounts at the plateau reached $0.97 \mathrm{mg} \mathrm{C} / \mathrm{m}^{2}$ and $0.22 \mathrm{mg} \mathrm{C} / \mathrm{m}^{2}$ at pH 6 and 8, respectively. Such values are of the same order of magnitude as those reported in the literature for the adsorption of humic substances on hematite and kaolinite in a similar $\mathrm{pH}$ range (Gu et al., 1994; Hur and Schlautman, 2003; Tipping, 1981; Vermeer et al., 1998).

The increased adsorption with decreasing $\mathrm{pH}$ is generally attributed to (i) a higher positive charge of the mineral oxide surface at acid $\mathrm{pH}$, and (ii) a change to a more compact conformation of humic acid. A specific adsorption of humic substances and a possible hydrophobic interaction are also frequently invoked to explain the results obtained at basic $\mathrm{pH}$ since an electrostatic repulsion between humic colloids and negatively-charged particles should occur under those conditions (Vermeer et al., 1998). In our case, it is likely that the divalent cation impurities, i.e. $\mathrm{Ca}$ and $\mathrm{Mg}$, brought by the addition of hydrogenocarbonate to the synthetic water, actively participate to the humic acid adsorption (Tipping, 1981). Indeed, ICP-AES measurements of the major ion contents of the supernatant (not shown here) revealed $\mathrm{Ca}$ and $\mathrm{Mg}$ concentrations in the ppm range after only 5 min adsorption. A small increase in those divalent concentrations was also noted after $24 \mathrm{~h}$ adsorption that may be attributed to a slight dissolution of pozzolana volcanic glass.

\subsection{Destabilization of $\mathrm{NHA}$ with ferric chloride in presence of pozzolana particles. In a} previous paper on the coagulation of Nyong humic acid with ferric chloride, Sieliechi et al., 
(2008) showed that, at a given coagulant concentration and independently of $\mathrm{pH}$, the formation of NHA aggregates is mainly governed by two dynamics aspects, namely the reconformation of humic network upon neutralization of the anionic functional groups with the oppositely charged Fe-coagulant species, and the collision rate of destabilized humic nanocolloids that determines the time scale allowed for the reconformation. Such interplay was found to determine drastic variations in the sediment volume according to the initial mixing conditions of the coagulated suspension (Sieliechi et al., 2008).

In the presence of varying concentrations of pozzolana particles (fig. 3a), the evolution of residual turbidity at $\mathrm{pH} 6$ as a function of coagulant concentration reveals that: (i) the turbidity of the uncoagulated suspension increases with pozzolana addition, which obviously corresponds to the addition of fine mineral particles which stability may be enhanced by the adsorption of humic acid (Tipping and Higgins, 1982). (ii) The optimal coagulant concentration (OCC), taken as the intersect with the $\mathrm{x}$-axis of the extrapolated steep decreasing portion of the turbidity curve, remains primarily determined by the presence of humic colloids even though a minor increase of OCC can be detected with pozzolana concentration. (iii) In the range of optimal dosing, the quality of the clarified water resulting from ballasted-aggregation is equivalent to that achieved without pozzolana except for the highest amount of ballasting agent added, for which a slight deterioration of the residual turbidity is noted; the latter observation is in accordance with previous studies of ballasted aggregation (Young and Edwards, 2003). (iv) The restabilization concentration notably increases with the largest amount of added pozzolana.

The jar-tests conducted at $\mathrm{pH} 8$ with a $500 \mathrm{ppm}$ addition of pozzolana (fig. $3 \mathrm{c}$ ) are consistent with those carried out at $\mathrm{pH}$ 6. The higher OCC and the broader destabilization domain determined at $\mathrm{pH} 8$ have been attributed to a combination of various factors including an increased deprotonation of NHA functional groups, a change to a stretched conformation 
of humic network that makes more binding sites available to coagulant species, and a smaller charge of hydrolyzed-Fe species at basic $\mathrm{pH}$ which necessarily implies that a larger amount of coagulant is needed to compensate the charge of humic colloids (Sieliechi et al., 2008).

According to the adsorption isotherms, the maximum amount of NHA adsorbed to the pozzolana particles only reaches $1 \mathrm{mg} \mathrm{C} / \mathrm{L}$ at the highest ballast concentration used (2000 ppm), i.e. less than $10 \%$ of the initial dissolved organic carbon. In other terms, the removal of NHA by adsorption is negligible compared with that performed by coagulation. As illustrated in figure $3 \mathrm{~b}$, the sediment volume measured in the region of optimum coagulation strongly diminishes at first with the addition of a small amount of ballasting agent, and then more slightly with further addition of mineral particles. Such a decrease in sediment volume is not influenced by a change in $\mathrm{pH}$ since a similar $50 \%$ reduction is achieved at both $\mathrm{pH} 6$ and 8 using a $500 \mathrm{ppm}$ addition of pozzolana (fig. 3d). Moreover, and surprisingly, the gain percentage in sediment volume resulting from the use of a ballasting agent does not significantly depend on settling time (fig. 4). Therefore, the decrease in sediment volume obtained after balasting agent addition is not primarily related to the time during which the pozzolana particles may compress the coagulated sediment, but mainly depends on the floc properties acquired before settling. In other terms, during floc growth, some restructuring of NHA aggregates must occur in the presence of ballasting agent, which then leads to a lower sediment volume.

It can also be noted that the small amount of sediment recorded before OCC corresponds to pozzolana not incorporated within NHA aggregates, and as a corollary, that the mineral particles are predominantly associated with the humic flocs within the range of optimum dosage. Figure 4 also clearly indicates that the influence of ballasting agent concentration on sediment volume levels off above $0.5 \mathrm{~g}$. Such a value, slightly lower than the microsand injection rate of $1.5 \mathrm{~g} / \mathrm{L}$ used in the $\mathrm{ACTIFLO}^{\circledR}$ process (Cailleaux et al., 1992), is 
consistent with the break in the evolution of floc water content versus ballast concentration reported by Ghanem et al. (2007).

3.3 Floc size and floc structure during ballasted-aggregation. A $0.5 \mathrm{~g} / \mathrm{L}$ addition of pozzolana particles was used to investigate the effect of ballast particles on the characteristics of NHA-hydrolyzed Fe aggregates. Figure 5 shows the temporal evolutions of the floc size distribution during the coagulation of NHA in the presence or in the absence of pozzolana particles at pH 6 and $\mathrm{pH} 8$ at or slightly below OCC. Except at the beginning of ballasted aggregation where the size distribution curve of ballasting agent can be evidenced (fig. $5 b$ ), the floc size distributions during floc growth are monomodal, similar in shape, and characterized by a pronounced skewness toward the smaller aggregate sizes. Such features are characteristic of the asymptotic growth in cluster-cluster aggregation (Friedlander, 1977). The size distribution curves superimpose when the $\mathrm{x}$-axis is normalized by the median floc diameter $\mathrm{d}_{50}$, and hence, the aggregation dynamics of NHA can be characterized by the time dependence of $\mathrm{d}_{50}$. As the median floc diameter increases proportionally with time during floc growth (fig. 5a-b), an aggregation rate coefficient can be calculated from the slope of the linear part. It should be noted that for coagulant concentrations higher than $2.3410^{-4} \mathrm{~mol} / \mathrm{L}$ and $5.110^{-4} \mathrm{~mol} / \mathrm{L}$ at $\mathrm{pH} 6$ and 8 , respectively, the maximum diameter reached at the end of floc growth is determined from a floc size distribution that is partially outside the size range allowed by the particle sizer. Therefore, the median floc diameters inferred from those size distribution curves are not reliable, and were not taken into account for the calculation of aggregation rate coefficients.

Interestingly, the lag time before the aggregate growth starts, defined as the intercept of the tangent to the $\mathrm{d}_{50}$-versus-time curve with the $\mathrm{x}$-axis (fig. 5a-b), significantly increases in the presence of pozzolana particles. The lag time includes the time to transport the 
coagulated suspension to the measurement cell (less than 5 seconds), and the time for the growing aggregates to reach the lower size detection limit of the laser sizer, i.e. $1.2 \mu \mathrm{m}$. Therefore, the increased lag time observed in the case of ballasted aggregation likely corresponds to a restructuring/compaction stage of NHA aggregates in the presence of pozzolana particles, that significantly delays the initial floc formation.

Figure 6a presents the evolution of aggregation rates at $\mathrm{pH} 6$ and 8 as a function of coagulant concentration in the presence and in the absence of pozzolana particles. Two aggregation regimes can be distinguished: below OCC, the aggregation kinetics during ballasted coagulation is either slower than $(\mathrm{pH}$ 6) or equivalent $(\mathrm{pH} 8)$ to that of conventional coagulation. In the vicinity of the optimum coagulant concentration and above OCC, the aggregation rate in the presence of pozzolana particles becomes significantly higher than that measured in absence of ballast particles. At first approximation, such higher aggregation rate coefficients can be explained by an enhanced participation of pozzolana particles to the formation of NHA aggregates, i.e. the ballasting agent is indeed incorporated within the flocs, whereas the lower growth kinetics recorded below OCC should reflect the initial floc restructuring in the presence of ballasting agent.

Typical determinations of the aggregates fractal dimension from the log-log plot of suspended floc volume versus $\mathrm{d}_{50}$, are shown in figure $6 \mathrm{~b}$. Obviously, the limited ranges of $\mathrm{d}_{50}$ used to calculate $\mathrm{D}_{\mathrm{f}}$, i.e. at best one decade in size, are not sufficient to provide a reliable estimate of slopes, and hence, it seems preferable to refer to $\mathrm{D}_{\mathrm{f}}$ as a fractal exponent rather than to a true fractal dimension. In addition, the method used implies that all the diffracted light by the flocs and the particles is counted by the detector, which may not be the case below OCC when part of the humic nanocolloids are not completely aggregated. Nevertheless, figure $6 \mathrm{~b}$ reveals contrasted situations in terms of aggregate structure for ballasted and conventional coagulation. The fractal exponents are about 2.0 and 1.5 in the presence and in 
the absence of pozzolana particles, respectively. These values, little affected by a change in $\mathrm{pH}$ or coagulant concentration, are lower than those previously reported in the literature for flocs formed from natural organic matter and hydrolyzing metal salts (Jarvis et al., 2005). However, the latter fractal dimensions, in the 2.2-2.5 range, were measured by small angle laser light scattering which generally provides a structural information at the micron scale of aggregates.

The higher fractal exponent found in the case of ballasted aggregation suggests a floc compaction induced by the presence of pozzolana particles, and is then fully consistent with the previous observations of a much lower sediment volume after settling and a longer lag time before floc growth or slower growth kinetics that can be detected by the laser particle sizer. Previous modelling studies have indeed shown that an increased fractal dimension decreases the initial aggregate growth rate (Flesch et al., 1999; Selomulya et al., 2003).

\subsection{TEM imaging of coagulated NHA. Figure 7 presents typical TEM micrographs of Nyong} humic acid coagulated in the presence and in the absence of ballasting agent (fig. 7a). Close to the OCC, the NHA aggregates appear as relatively tenuous structures essentially made of nanometer size humic colloids and a few dispersed electron dense spots with a mean diameter of $5 \mathrm{~nm}$ (fig. 7a). According to Sieliechi et al. (2008), those electron-dense granules result from the reconformation of anionic humic colloids upon binding with the positive Fehydrolyzed species, and their number and size increase at lower coagulant concentration. The pozzolana corresponds to the highly fractured electron-opaque particles (fig. $7 \mathrm{~b}-\mathrm{d}$ ), the microfracturation of particles with part of material wrenched away occurring during the cutting of 80-100 nm thick slices with the diamond knife.

Even though the resin-embedding procedure is certainly not artifact-free, the quantification of the fractal dimension of NHA aggregates using ImageJ, yielded similar $\mathrm{D}_{\mathrm{f}}$ 
values of $1.5 \pm 0.5$ at the micron scale, for both structures obtained in the absence and in the presence of pozzolana particles (fig. 7a-b). If such $\mathrm{D}_{\mathrm{f}}$ value is consistent with the fractal exponent estimated by laser diffraction during the conventional coagulation of NHA, a higher fractal dimension might be expected for ballasted aggregation. Actually, the two-dimensional projection of an aggregate of fractal dimension equal to (or greater than) 2 should lead to a compact pattern on a TEM micrograph (Meakin, 1988). This suggests that the restructuring of NHA aggregates induced by the presence of ballasting agent occurs beyond the micron scale. A similar effect, i.e. an increase of fractal dimension with floc size due to restructuring above the micron scale, has been reported for iron hydroxide flocs (Jung et al., 1996) and for coagulated latex particles (Oles, 1992). Confirmation of a larger scale restructuring can be found in fig. 7b-d where no particular differentiation of NHA aggregates may be detected in the vicinity of pozzolana particles. Examination of figures $7 \mathrm{~b}-\mathrm{d}$ also indicate that the ballasting agent is simply incorporated in the aggregate during floc growth and do not seem to play a nucleus role as has been suggested in previous literature (Cailleaux et al., 1992).

\section{DISCUSSION}

The primary goal of ballasted aggregation is to form flocs of high specific weight in order to improve the clarification performance. It is generally acknowledged that, in addition to an increased density due to the incorporated ballast particles, such process should generate more compact flocs to withstand the stronger agitation required to maintain in suspension the ballasting agent (Cailleaux et al., 1992, Young and Edwards, 2003). This study provides experimental evidences - higher fractal dimension of aggregates above the micron scale, increased lag time before measurable floc growth, smaller sediment volume - of such

restructuring in the case of coloured water treated with ferric chloride. Previous literature had 
demonstrated that an aggregate compaction can be obtained with neutralized latex particles (Oles, 1992; Selomulya et al., 2002; Selomulya et al., 2003), but until now, the generalization of such results to colloidal systems relevant to water treatment had not been fully satisfactory (Jarvis et al., 2005; Mark and Flora, 1991).

Current thinking suggests that larger aggregates should be more sensitive to fluid shear stress, and hence to restructuring, than smaller flocs (Bache, 2004). However, the lag time before ballasted floc growth is effectively initiated, implies that most of the aggregate restructuring occurs at the start of floc formation. In turbulent flow conditions, the Kolmogorov length scale $\eta$ separates the inertial subrange from the viscous subrange:

$$
\eta=\left(\frac{v}{\gamma}\right)^{1 / 2}
$$

in which $v$ is the kinematic viscosity and $\bar{\gamma}_{\text {is }}$ the mean velocity gradient in the reactor. In our case, $v=10^{-6} \mathrm{~m}^{2} \mathrm{~s}^{-1}$ and $\bar{\gamma}=452 \mathrm{~s}^{-1}$, and hence $\eta=47 \mu \mathrm{m}$, which suggests that the floc restructuring in the presence of pozzolana particles should be dominated by viscous effects. Within that framework, an average degree of floc compaction $\chi$ can be estimated as follows: a floc will be rearranged during the collision with a single particle of ballasting agent if the resulting shear stress $\tau$ exceeds the floc yield stress. The shear stress $\tau$ can be assessed by (Thomas, 1964; Tomi and Bagster, 1978):

$$
\tau=\Delta \rho{\overline{U^{\prime}}}^{2}(2)
$$

in which $\Delta \rho=\rho_{\mathrm{pz}}-\rho_{\mathrm{w}}, \rho_{\mathrm{pz}}$ and $\rho_{\mathrm{w}}$ referring to the pozzolana density and the density of water, respectively, $\overline{U^{\prime}}$ represents the turbulent velocity fluctuations over the size $\mathrm{D}_{\mathrm{pz}}$ of a pozzolana particle, i.e. the root mean square value of the difference in relative velocity over the length scale $\mathrm{D}_{\mathrm{pz}}$, and $\Delta \rho \bar{U}^{\prime 2}$ is the variation of momentum during the floc/ballasting agent collision. 


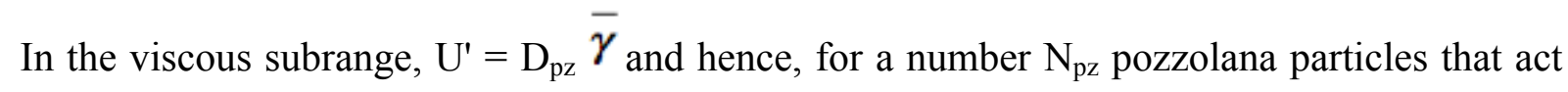
onto a floc, the shear stress is given by:

$$
\tau=N_{p z} \Delta \rho{\overline{U^{\prime}}}^{2}=N_{p z} \Delta \rho D_{p z}^{2} \bar{\gamma}^{2}(3)
$$

Previous studies have shown that an elastic floc model adequately describes the viscous flow behaviour of a coagulated colloidal suspension (Ekdawi and Hunter, 1983; Firth and Hunter, 1976) and the evolution of the floc cohesive force with floc size (Frappier et al., 2010). Let $\mathrm{E}$ and $\mathrm{G}$ be the Young's and shear modulus of the floc, respectively, and let $\mathrm{D}$ be the characteristic floc size. E and G satisfy (Denn, 1980; Metzener 1961):

$$
E \frac{\Delta D}{D}=2 \frac{\tau^{2}}{G}(4)
$$

As $\mathrm{G}$ and $\mathrm{E}$ are of the same order of magnitude, equation (4) can be rewritten as:

$$
\frac{\Delta D}{D}=2 \frac{\tau^{2}}{G^{2}}(5)
$$

When the viscous shear stress reaches the floc yield stress, $\mathrm{G} \sim \mu \bar{\gamma}$, in which $\mu$ is the fluid viscosity. Hence, using equation (3), equation (5) can be expressed as:

$$
\frac{\Delta D}{D}=2 \frac{\left(N_{p z} \Delta \rho D_{p z}^{2} \bar{\gamma}^{2}\right)^{2}}{(\mu \bar{\gamma})^{2}}=2 \frac{N_{p}^{2} \Delta \rho^{2} D_{p z}^{4} \bar{\gamma}^{2}}{\mu^{2}}(6)
$$

Let $\phi_{\mathrm{f}}$ and $\phi_{\mathrm{pz}}$ be the floc and pozzolana volume fractions, respectively. By definition:

$$
\Phi_{f}=\frac{V_{f}}{V}(7) \quad \Phi_{p z}=\frac{N_{p z} V_{p z}}{V}(8)
$$

in which $\mathrm{V}_{\mathrm{f}}$ is the floc volume, $\mathrm{V}_{\mathrm{pz}}$ is the volume of a single pozzolana particle, and $\mathrm{V}$ a reference volume of fluid. By dividing equation (8) by equation (7), we obtain:

$$
N_{p z}=\frac{\Phi_{p z}}{\Phi_{f}} \frac{V_{f}}{V_{p z}} \sim \frac{\Phi_{p z}}{\Phi_{f}}\left(\frac{D}{D_{p z}}\right)^{3}(9)
$$


Finally, the average degree of floc compaction $\chi$ can be written:

$$
\chi=\frac{D^{3}-(D-\Delta D)^{3}}{D^{3}}=1-\left(1-\frac{\Delta D}{D}\right)^{3}
$$

By substituting equation (9) to equation (6), we find:

$$
\chi=1-\left(1-2\left(\frac{\Phi_{p z}}{\Phi_{f}}\right)^{2} \frac{\Delta \rho^{2} D^{6} \bar{\gamma}^{2}}{\mu^{2} D_{p z}^{2}}\right)^{3}
$$

Two variables, i.e. $\mathrm{D}$ and $\phi_{\mathrm{pz}} / \phi_{\mathrm{f}}$, are particularly difficult to estimate as they strongly depend on when the floc restructuring occurs. If early restructuring at the micron scale range is favoured, both $\phi_{\mathrm{pz}}$ and $\phi_{\mathrm{f}}$, and $\mathrm{D}$ and $\mathrm{D}_{\mathrm{pz}}$, should be of the same order of magnitude. Using $\Delta \rho=1400 \mathrm{~kg} / \mathrm{m}^{3}, \mu=10^{-3}$ pa.s, $\mathrm{D}_{\mathrm{pz}}=10 \mu \mathrm{m}$, and $\phi_{\mathrm{pz}}=\phi_{\mathrm{f}}$, values of $\chi$ equal to $0.024,0.25$, and 0.88 are calculated for $\mathrm{D}$ equal to $10 \mu \mathrm{m}, 15 \mu \mathrm{m}$, and $20 \mu \mathrm{m}$, respectively. Therefore, our simple model can predict values of floc compaction in the presence of pozzolana particles that are consistent with the experimental results (e.g. $\chi$ of about 0.5 for a 500 ppm addition of ballasting agent in figure 4).

Nevertheless, it is difficult at the moment to provide more precise values of D or $\phi_{\mathrm{f}}$, especially that our model do not take into account the change in floc mechanical properties during compaction, and in particular the increase in floc yield stress that occurs with increased compaction (Seto et al., 2012).

\section{CONCLUSION}

The results presented in this paper shed new light on the mechanisms involved during ballasted aggregation. In particular, the addition of particles induces a floc compaction that contributes to the increased settling velocity of ballasted flocs. If the coagulation of humic 
acid is not significantly affected by the presence of pozzolana particles - the higher initial turbidity of suspensions only slightly increases the optimal coagulant concentration - the incorporation of ballast particles drastically modifies the timescale of floc growth and the fractal structure of flocs, which eventually leads to a smaller sediment volume for a residual turbidity equivalent to that observed in the absence of ballast particles. It is also worth noting that the pozzolana particles do not seem to act as a nucleus during floc formation.

Such observations open up new possibilities to further improve clarification processes based on ballasted aggregation. In industrial practice, a polymer is usually added to maintain an adequate cohesion of flocs. Our study reveals that both a good settling performance and an efficient turbidity removal may be obtained in the difficult case of humic-rich raw waters without adding polymer. As the presence of polymer might interfere with the phenomenon of floc compaction induced by the ballast particles, further research should address the complex interplay between polymer-enhanced floc cohesion and increased compaction of ballasted flocs.

Acknowledgments: We thank the French embassy in Cameroon for granting a fellowship to J. Sieliechi and for partial funding of this work.

\section{REFERENCES}

Bache, D.H., 2004. Floc rupture and turbulence: a framework for analysis. Chem. Eng. Sci. $59,2521-2534$.

Bache, D.H., Gregory, R., 2007. Flocs in water treatment. IWA Publishing.

Becker, V., Schlauch, E., Behr, M., Briesen, H., 2009. Restructuring of colloidal aggregates in shear flows and limitations of the free-draining approximation. J. Colloid Interface Sci. $339(2), 362-372$.

Cailleaux, C., Pujol, E., de Dianous, F., Druoton, J. C., 1992. Study of weighted flocculation in view of a new type of clarifier. J. Water SRT-Aqua 41(1), 18-27.

Cetin, U., Mehta, R.K., 1999. Sorption of uranium, strontium, and cesium on pozzolan. Min. 
Eng. 51(11), 31-36.

Chaignon, V., Lartiges, B.S., El Samrani, A.G., Mustin, C., 2002. Evolution of size distribution and transfer of mineral particles between flocs in activated sludges: an insight into floc exchange dynamics. Water Res. 36(3), 676-684.

Clark, M.M., Flora, J.R.V. 1991. Floc restructuring in varied turbulent mixing. J. Colloid Interface Sci. 147(2), 407-421.

de Dianous, F., Dernaucourt, J.C., 1991. Advantages of weighted flocculation in water treatment. Water Supp. 9, S43-S46.

Defontaine, G., Thormann, J., Lartiges, B.S., El Samrani, A.G., Barres, O., 2005. Incorporation of hydrophobized mineral particles in activated sludge flocs: a way to assess ballasting efficiency. Wat. Sci. Technol. 52(10-11), 177-184.

Denn, M.M., 1980. Process fluid mechanics. Prentice Hall Inc.

Desjardins, C., Koudjonou, B., Desjardins, R., 2002. Laboratory study of ballasted flocculation. Water Res., 36, 744-754.

Eikebrokk, B., 1999. Coagulation-direct filtration of soft, low alkalinity humic waters. Wat. Sci. Tech. 40(9), 55-62.

Ekdawi, N., Hunter, R.J., 1983. Couette flow behaviour of coagulated colloidal suspensions. VI. The elastic floc model at low shear rates. J. Colloid Interface Sci. 94(2), 355-361.

Firth, B.A., Hunter, R.J., 1976. Flow properties of coagulated colloidal suspensions. III. The elastic floc model. J. Colloid Interface Sci. 57(2), 266-275.

Flesch, J.C., Spicer, P.T., Pratsinis, S.E., 1999. Laminar and turbulent shear-induced flocculation of fractal aggregates. AIChE J. 45(5), 1114-1124.

Frappier, G., Lartiges, B.S., Skali-Lami, S., 2010. Floc cohesive force in reversible aggregation: a Couette laminar flow investigation. Langmuir 26(13), 10475-10488.

Friedlander, S.K., 1977. Smoke, Dust and Haze. Wiley, New York.

Gasperi, J., Laborie, B., Rocher, V., 2012. Treatment of combined sewer overflows by ballasted flocculation: Removal study of a large broad spectrum of pollutants. Chem. Eng. J. 211, 293-301.

Ghanem, A.V., Young, J.C., Edwards, F.G., 2007. Mechanisms of ballasted floc formation. J. Environ. Eng. 133(3), 271-277.

Gu, B., Schmitt, J., Chen, Z., Liang, L., McCarthy, J.F., 1994. Adsorption and desorption of natural organic matter on iron oxide: mechanisms and models. Environ. Sci. Technol. 28, 3846. 
Hur, J., Schlautman, M.A., 2003. Molecular weight fractionation of humic substances by adsorption onto minerals. J. Colloid Interface Sci. 264(2), 313-321.

Jarvis, P., Jefferson, B., Parsons S.A., 2005. How the natural organic matter to coagulant ratio impacts on floc structural properties. Environ. Sci. Technol. 39, 89-19-8924.

Jung, S.B., Amal, R., Raper, J.A., 1996. Monitoring effects of shearing on floc structure using small angle light scattering. Powder Technol. 88(1), 51-54.

Jung, A.-V., Frochot, C., Parant, S., Lartiges, B.S., Selve, C., Viriot, M.-L., Bersillon, J.-L., 2005. Synthesis of amino-phenolic humic-like substances and comparison with natural aquatic humic acids: a multi-analytical techniques approach. Org. Geochem. 36(9), 12521271.

Lapointe, M., Barbeau, B., 2016. Characterization of ballasted flocs in water treatment using microscopy. Water Res. 90, 119-127.

Meakin, P., 1988. Fractal aggregates. Adv. Colloid Interface Sci. 28, 249-331.

Metzener, A.B., 1961. Flow of non-Newtonian fluids. In: Handbook of fluid mechanics, section 7. McGraw-Hill book Co Inc..

Oles, V., 1992. Shear-induced aggregation and breakup of polystyrene latex particles. J. Colloid Interface Sci. 154(2), 351-358.

Piirtola, L., Hultman, B., Lowen, M. 1999. Activated sludge ballasting in pilot plant operation. Water Res. 33(13), 3026-3032.

Plum, V., Dahl, C. P., Bentsen, L., Petersen, C. R., Napstjert, L., Thomsen, N. B., 1998. The Actiflo method. Wat. Sci. Tech. 37(1), 269-275.

Selomulya, C., Amal, R., Bushell, G., Waite, T.D., 2001. Evidence of shear rate dependence on restructuring and breakup of latex aggregates. J. Colloid Interface Sci. 236, 67-77.

Selomulya, C., Bushell, G., Amal, R., Waite, T.D., 2003. Understanding the role of restructuring in flocculation: the application of a population balance model. Chem. Eng. Sci. $58,327-338$.

Serra, T., Casamitjana, X., 1998. Structure of the aggregates during the process of aggregation and breakup under a shear flow. J. Colloid Interface Sci. 206(2), 505-511.

Sersale, R., 1980. Structure and characterisation of pozzolonas and fly ashes. In: Proceedings of the $7^{\text {th }}$ symposium on the chemistry of cement. Paris, Vol. 1 IV 1/3.

Seto, R., Botet, R., Auernhammer, G.K., Briesen, H., 2012. Restructuring of colloidal aggregates in shear flow coupling interparticle contact models with Stokesian dynamics. Eur. Phys. J. E 35(12), Article Number 128.

Sieliechi, J.-M., Lartiges, B.S., Kayem, G.J., Hupont, S., Frochot, C., Thieme, J., Ghanbaja, J., d'Espinose de la Caillerie, J.B., Barrès, O., Kamga, R., Levitz, P., Michot, L.J., 2008. Changes 
in humic acid conformation during coagulation with ferric chloride: Implications for drinking water treatment. Water Res. 42, 2111-2123.

Spicer, P.T., Pratsinis, S.E., Raper, J., Amal, R., Bushell, R., Meesters, G., 1998. Effect of shear schedule on particle size, density, and structure during flocculation in stirred tanks. Powder Technol. 97, 26-34.

Tambo, N., Watanabe, Y., 1979. Physical characteristics of flocs I. The floc density and aluminium floc. Water Res. 13(5), 409-471.

Thill, A., Aziz, J., Lambert, S., Moustier, S., Wiesner, M.M., Bottero, J.Y., 2001. Flocs restructuring during aggregation: experimental evidence and numerical simulation. J. Colloid Interface Sci. 243, 171-182.

Thomas, D.G., 1964. Turbulent disruption of flocs in small particle size suspensions. AIChE J. 10(4), 517-523.

Thurman E.M., Malcolm, R.L. 1981. Preparative isolation of aquatic humic substances. Environ. Sci. Technol. 15(4), 463-466.

Tipping, E., 1981. The adsorption of aquatic humic substances by iron oxides. Geochim. Cosmochim. Acta 45, 191-199.

Tipping, E., Higgins, D.C., 1982. The effect of humic substances on the colloid stability of hematite particles. Colloids Surf. 5, 85-92.

Tomi, D.T., Bagster, D.F., 1978. The behaviour of aggregates in stirred vessels. Part I Theoretical considerations on the effects of agitation. Trans. Inst Chem. Eng. 56, 1-8.

Vermeer, A.W.P., van Riemsdijk, W.H., Koopal, L.K., 1998. Adsorption of humic acid to mineral particles. 1. Specific and Electrostatic interactions. Langmuir 14, 2810-2819.

Weiner, B.B., 1984. In: Barth. Modern methods of particle size analysis. Wiley-Interscience. Chap. 5, 135-172.

Young, J.C., Edwards, F.G., 2003. Factors affecting ballasted flocculation reactions. Water Environ. Res. 75(3), 263-272.

Yukselen, M.A., Gregory, J., 2004. The effect of rapid mixing on the break-up and reformation of flocs. J. Chem. Technol. Biotechnol. 79(7), 782-788. 
Table 1: Fitting parameters of Langmuir adsorption isotherms.

\begin{tabular}{|c|c|c|c|}
\cline { 2 - 4 } \multicolumn{1}{c|}{} & Adsorption time & $\mathbf{Q}_{\max }\left(\mathbf{m g} / \mathbf{m}^{2}\right)$ & $\mathbf{K}(\mathbf{L} / \mathbf{m g})$ \\
\hline \multirow{2}{*}{ pH 6 } & $5 \mathrm{~min}$ & 0.23 & 0.54 \\
\cline { 2 - 4 } & $24 \mathrm{~h}$ & 0.97 & 0.65 \\
\hline \multirow{2}{*}{ pH 8 } & $5 \mathrm{~min}$ & 0.20 & 0.17 \\
\cline { 2 - 4 } & $24 \mathrm{~h}$ & 0.22 & 0.47 \\
\hline
\end{tabular}

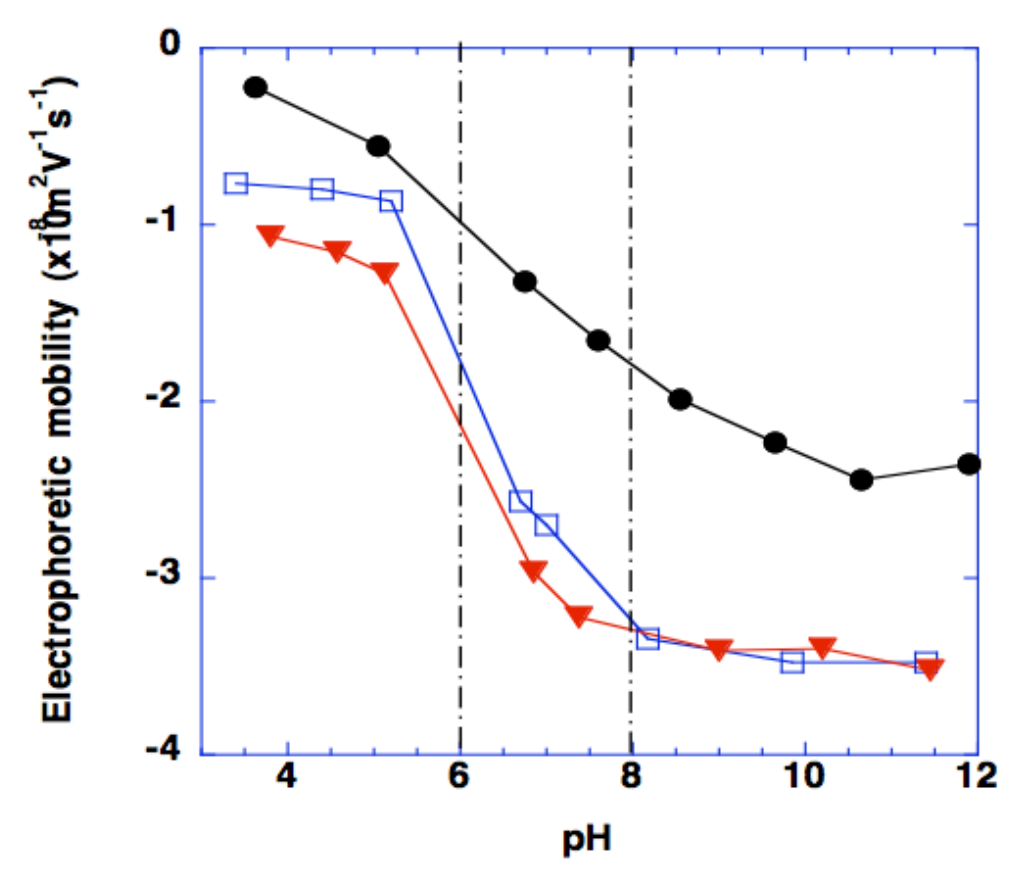

Figure 1: Electrophoretic mobility of Djoungo pozzolana as a function of $\mathrm{pH}$ : - KCl $10^{-1} \mathrm{M}, \square \mathrm{KCl} 10^{-2} \mathrm{M}, \nabla \mathrm{KCl} 10^{-3} \mathrm{M}$. 

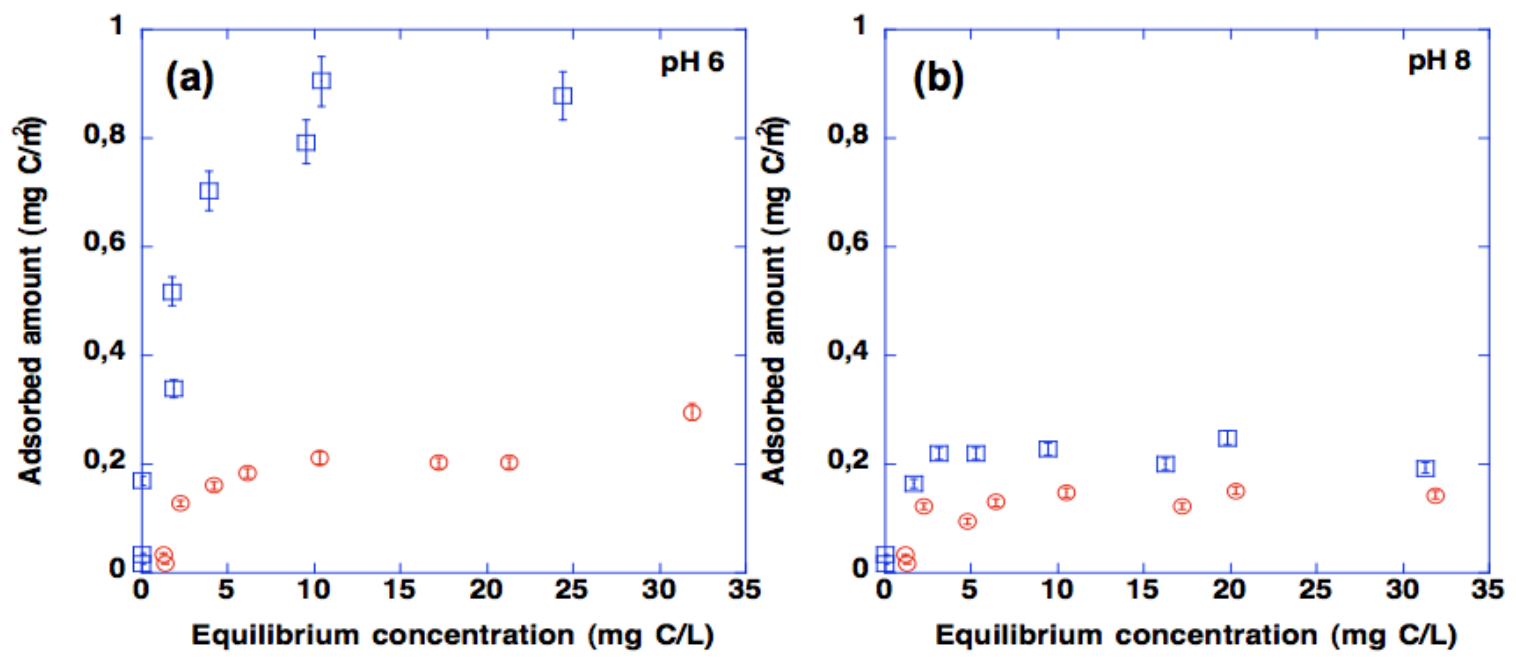

Figure 2: Adsorption isotherms of NHA onto Djoungo pozzolana after an equilibrium time of $5 \mathrm{~min}(\mathrm{O})$ and $24 \mathrm{~h}(\square)$. (a) $\mathrm{pH} 6$ and (b) $\mathrm{pH} 8$.
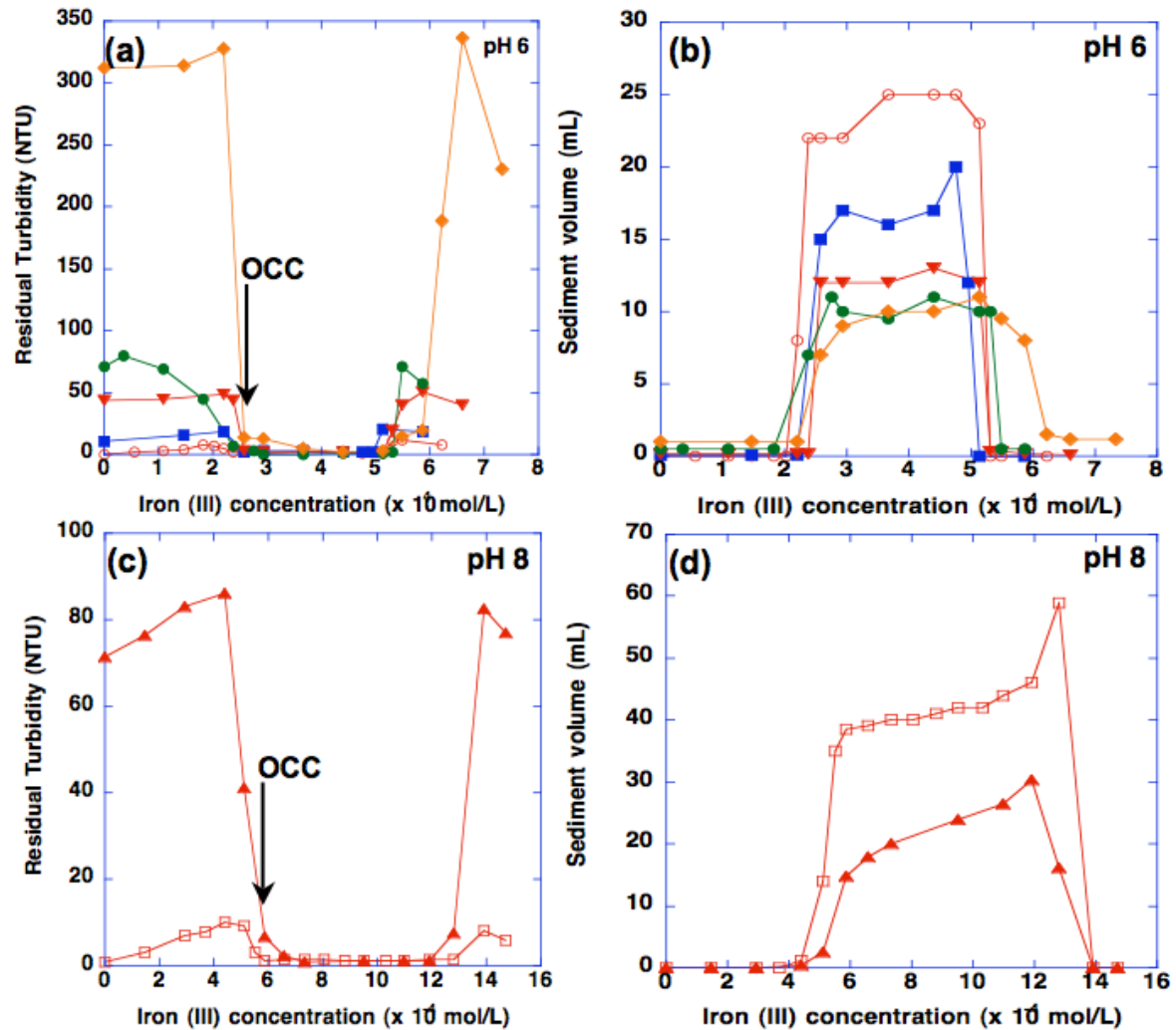

Figure 3: Residual turbidity and sediment volume after $30 \mathrm{~min}$. settling as a function of coagulant concentration in the presence of various concentrations of pozzolana. (a) and (b) pH 6; pozzolana concentrations of 0 ppm (O), 50 ppm (匹), 200 ppm ( $\nabla), 500$ ppm (O), 2000 ppm ( $)$ ). (c) and (d) pH 8; pozzolana concentrations of $0 \mathrm{ppm}(\square), 500 \mathrm{ppm}(\Delta)$. The arrows indicate the optimum coagulant concentrations $(\mathrm{OCC})$ in the absence of pozzolana. 


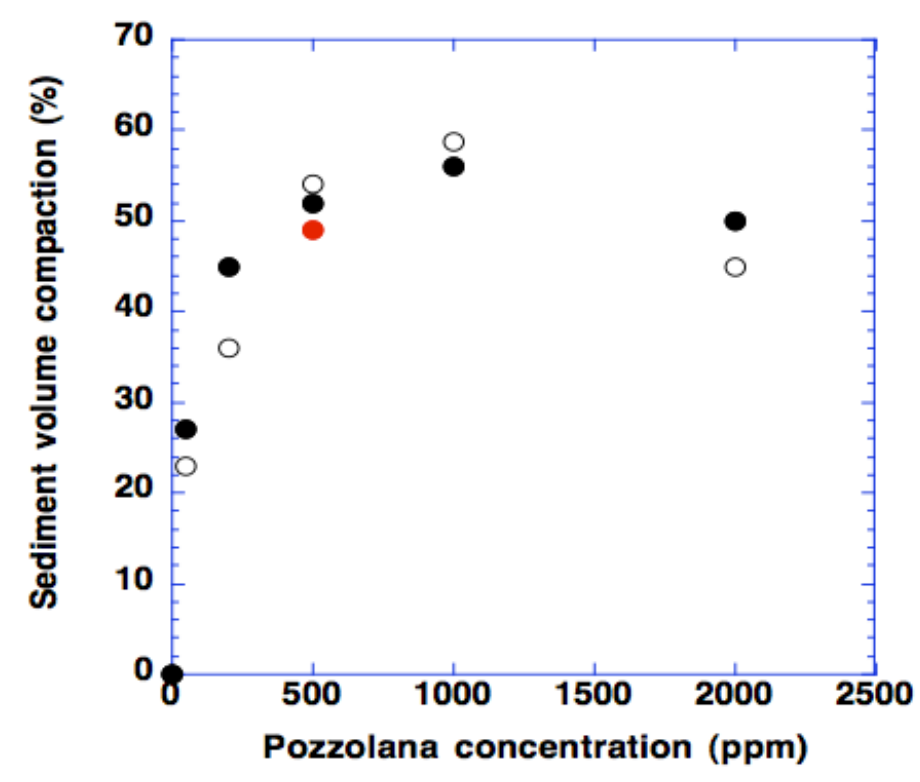

Figure 4: Sediment volume compaction versus pozzolana concentration: - $(\mathrm{pH} 6)$ and $(\mathrm{pH} 8)$ sediment volumes measured after 30 min settling. $\mathrm{O}(\mathrm{pH} 6)$ sediment volumes measured after $24 \mathrm{~h}$ settling.
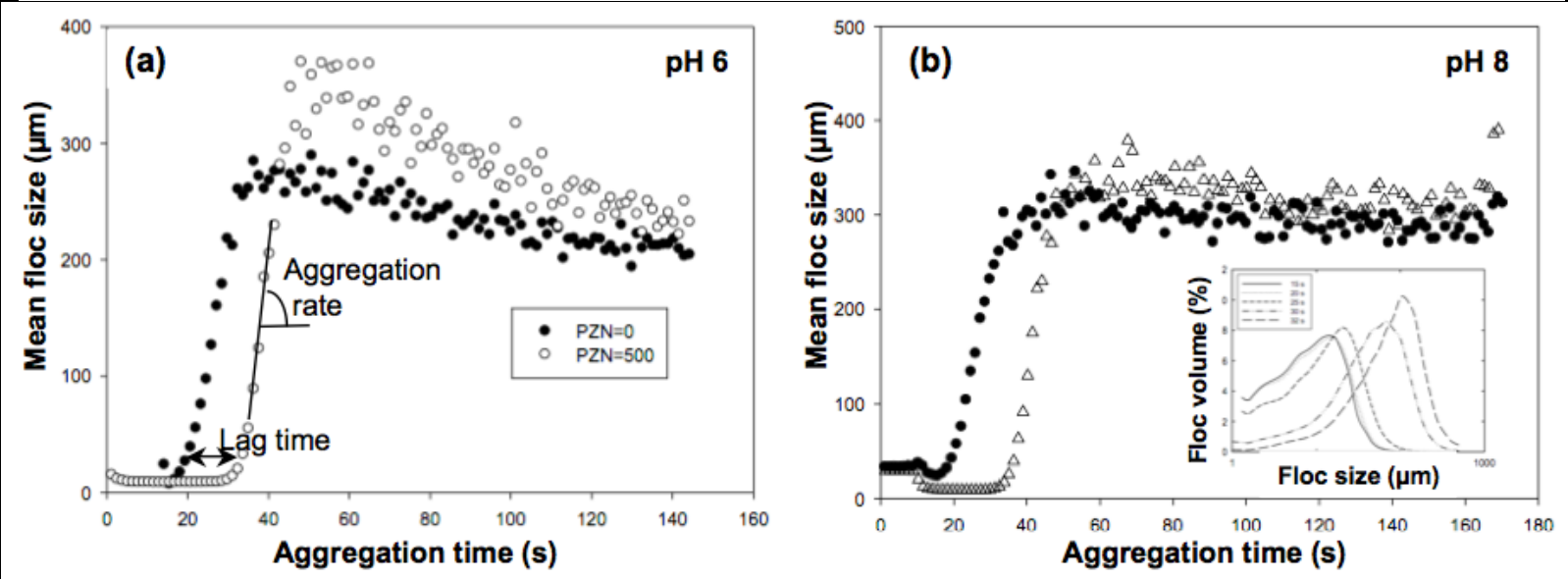

Figure 5: Temporal evolution of mean floc size in the presence (open symbols) or in the absence of pozzolana particles (filled symbols).

(a) $[\mathrm{Fe}]=2.5710^{-4} \mathrm{~mol} / \mathrm{L}$ and $\mathrm{pH} 6$; (b) $[\mathrm{Fe}]=5.510^{-4} \mathrm{~mol} / \mathrm{L}$ and $\mathrm{pH} 8$.

The inset shows the evolution of monomodal floc size distribution at the beginning of floc growth. 

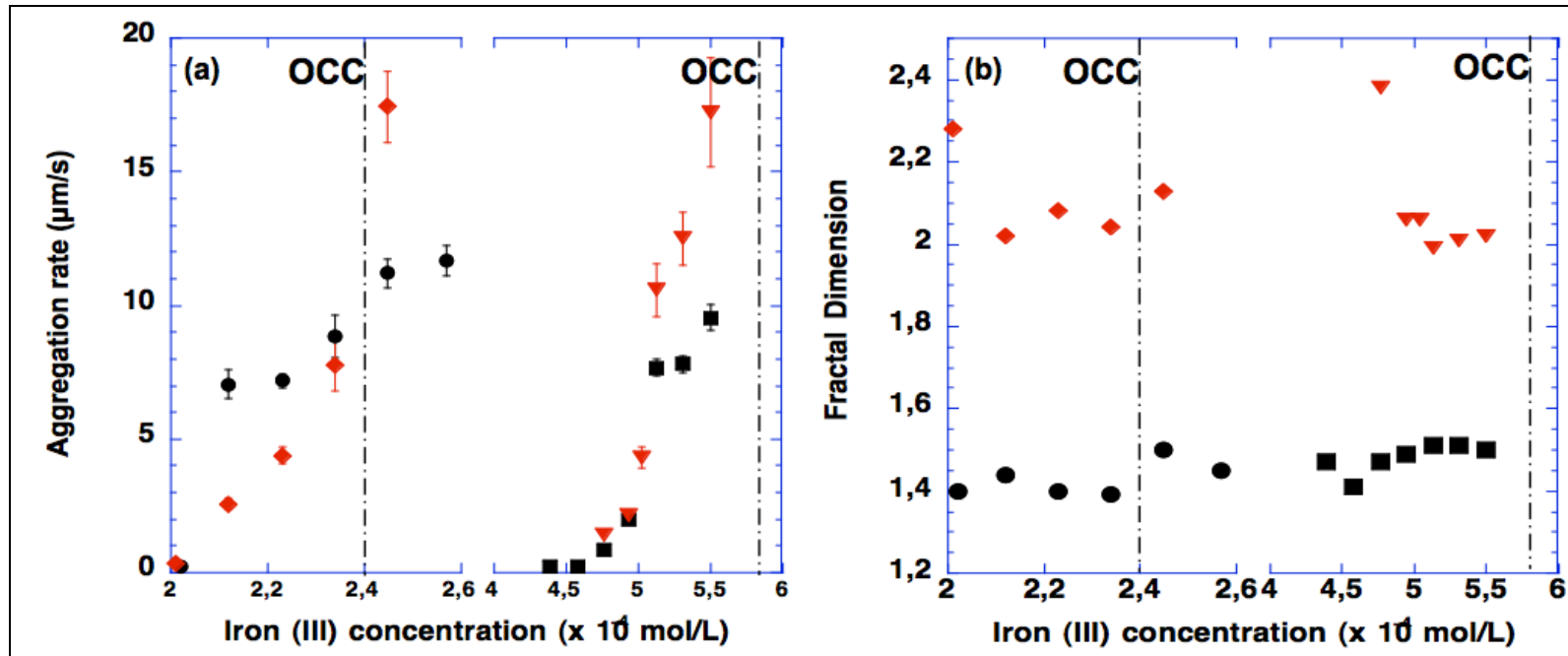

Figure 6: Evolution as a function of Iron (III) concentration of (a) the aggregation rate and $\begin{array}{ll}\text { (b) the fractal dimension of flocs. }(\bullet) \mathrm{pH} 6 \text { and no pozzolana added; } & (\boldsymbol{\square}) \mathrm{pH} 8 \text { and no }\end{array}$ pozzolana added; $(\diamond) \mathrm{pH} 6$ and $500 \mathrm{ppm}$ pozzolana added; $(\nabla) \mathrm{pH} 8$ and $500 \mathrm{ppm}$ pozzolana added.The dotted lines indicate the optimal coagulant concentrations (OCC).
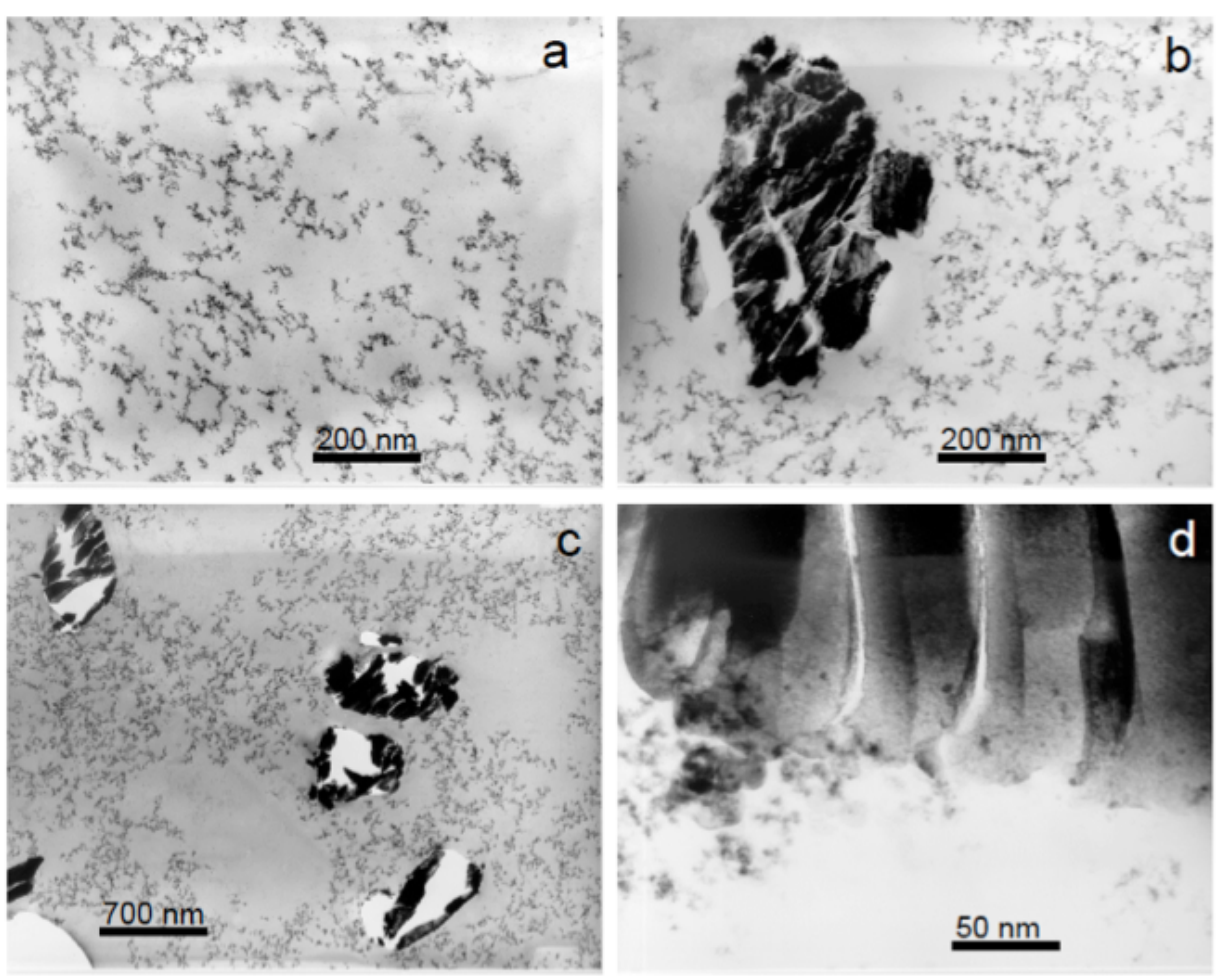

Figure 7: Typical electron micrographs of NHA flocs in the absence (a) and in the presence of pozzolana particles (b-d). (a) $[\mathrm{Fe}]=2.3410^{-4} \mathrm{~mol} / \mathrm{L}$ at pH 6; (b) $[\mathrm{Fe}]=$ $5.510^{-4} \mathrm{~mol} / \mathrm{L}$ at pH 8 and $500 \mathrm{ppm}$ of added pozzolana; (c) $[\mathrm{Fe}]=2.3410^{-4} \mathrm{~mol} / \mathrm{L}$ at pH 6 and $500 \mathrm{ppm}$ of added pozzolana; (d) Close-up of the contact between $\mathrm{NHA}$ aggregate and pozzolana particle. 
Table S1: Chemical composition of Djoungo pozzolana (Oxides are expressed as weight percentage and trace elements as ppm)

\begin{tabular}{|l|l|l|l|l|l|l|l|l|l|l|l|}
\hline $\mathrm{SiO}_{2}$ & $\mathrm{Al}_{2} \mathrm{O}_{3}$ & $\mathrm{Fe}_{2} \mathrm{O}_{3}$ & $\mathrm{MnO}$ & $\mathrm{MgO}$ & $\mathrm{CaO}$ & $\mathrm{Na}_{2} \mathrm{O}$ & $\mathrm{K}_{2} \mathrm{O}$ & $\mathrm{TiO}_{2}$ & $\mathrm{P}_{2} \mathrm{O}_{5}$ & P.F. & Total \\
\hline 46,08 & 16,43 & 12,65 & 0,18 & 5,51 & 9,62 & 3,9 & 1,51 & 2,88 & 0,52 & $-0,28$ & 99 \\
\hline $\mathrm{Sr}=689.8$ & $\mathrm{Ba}=423.8$ & $\mathrm{Zr}=273.8$ & $\mathrm{~V}=206.7$ & $\mathrm{Cr}=145.5$ & $\mathrm{Zn}=116.1$ & $\mathrm{Ce}=89.4$ & $\mathrm{Cu}=49.61$ & $\mathrm{Nb}=57.1$ \\
\hline $\mathrm{Ni}=49.1$ & $\mathrm{La}=45.2$ & $\mathrm{Nd}=42.2$ & $\mathrm{Co}=34.4$ & $\mathrm{Rb}=33.1$ & $\mathrm{Ga}=21.5$ & $\mathrm{Y}=26.1$ & $\mathrm{Sm}=8.3$ & $\mathrm{Gd}=7.1$ \\
\hline
\end{tabular}

